\title{
Benthic Community Structure and Composition in Sediment from the Northern Gulf of Mexico Shoreline, Texas to Florida
}

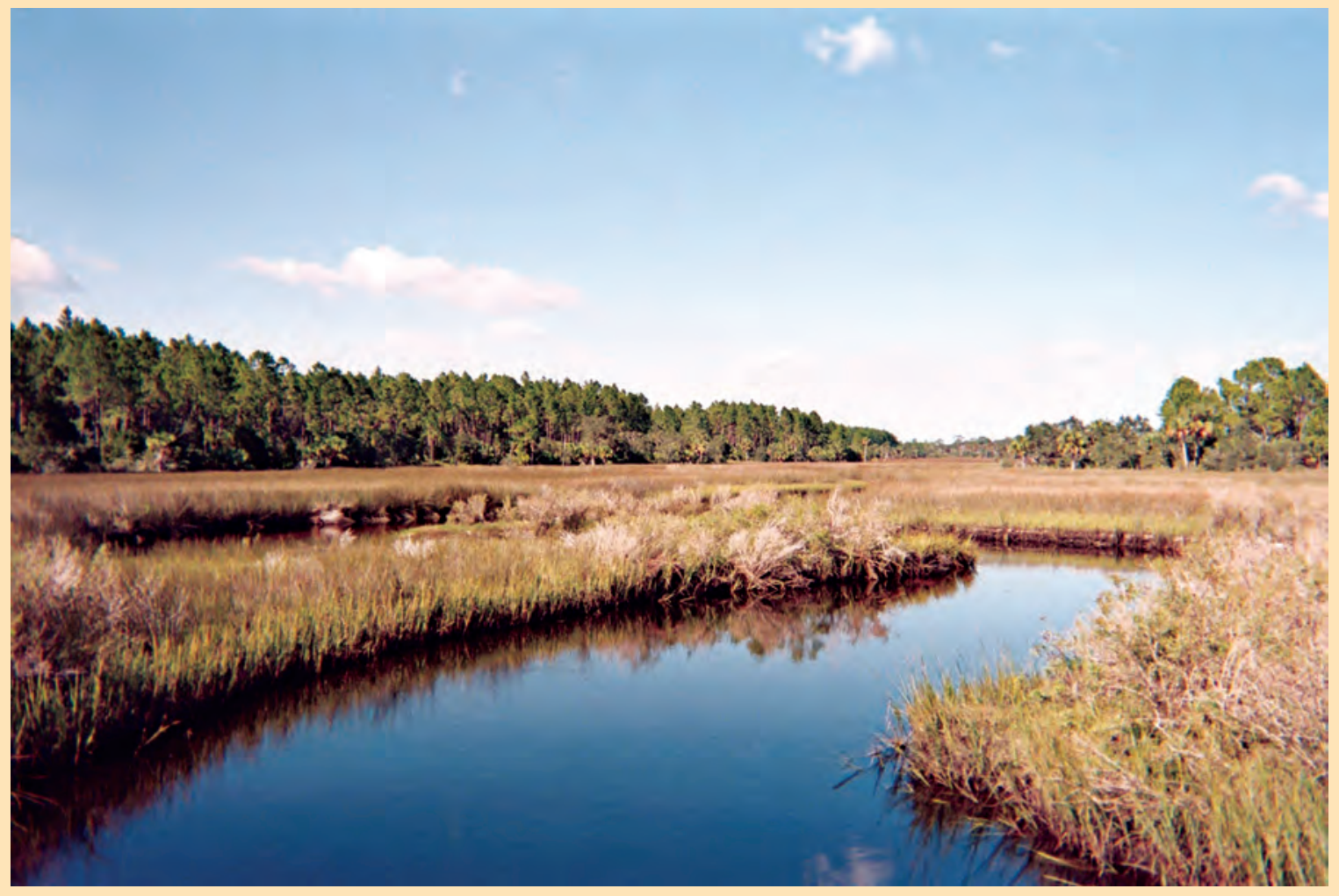

Open-File Report 2012-1153 
Front cover

Dennis Creek as seen from the access road to Shell Mound in the Lower Suwannee National Wildlife Refuge near Cedar Key, Florida.

Image provided by Douglas Strom of

Water \& Air Research, Inc., Gainesville, Florida. 


\section{Benthic Community Structure and Composition in Sediment from the Northern Gulf of Mexico Shoreline, Texas to Florida}

By Amanda W.J. Demopoulos and Douglas G. Strom

Open-File Report 2012-1153 


\title{
U.S. Department of the Interior \\ KEN SALAZAR, Secretary \\ U.S. Geological Survey \\ Marcia K. McNutt, Director
}

\author{
U.S. Geological Survey, Reston, Virginia: 2012
}

For more information on the USGS - the Federal source for science about the Earth, its natural and living resources, natural hazards, and the environment, visit http://www.usgs.gov or call 1-888-ASK-USGS.

For an overview of USGS information products, including maps, imagery, and publications, visit http://www.usgs.gov/pubprod

To order this and other USGS information products, visit http://store.usgs.gov

Any use of trade, firm, or product names is for descriptive purposes only and does not imply endorsement by the U.S. Government.

Although this information product, for the most part, is in the public domain, it also may contain copyrighted materials as noted in the text. Permission to reproduce copyrighted items must be secured from the copyright owner.

Suggested citation:

Demopoulos, A.W.J., and Strom, D.G., 2012, Benthic community structure and composition in sediment from the northern Gulf of Mexico shoreline, Texas to Florida: U.S. Geological Survey Open-File Report 2012-1153, 15 p., (also available at $h$ ttp://pubs.usgs.gov/of/2012/1153/. 


\section{Contents}

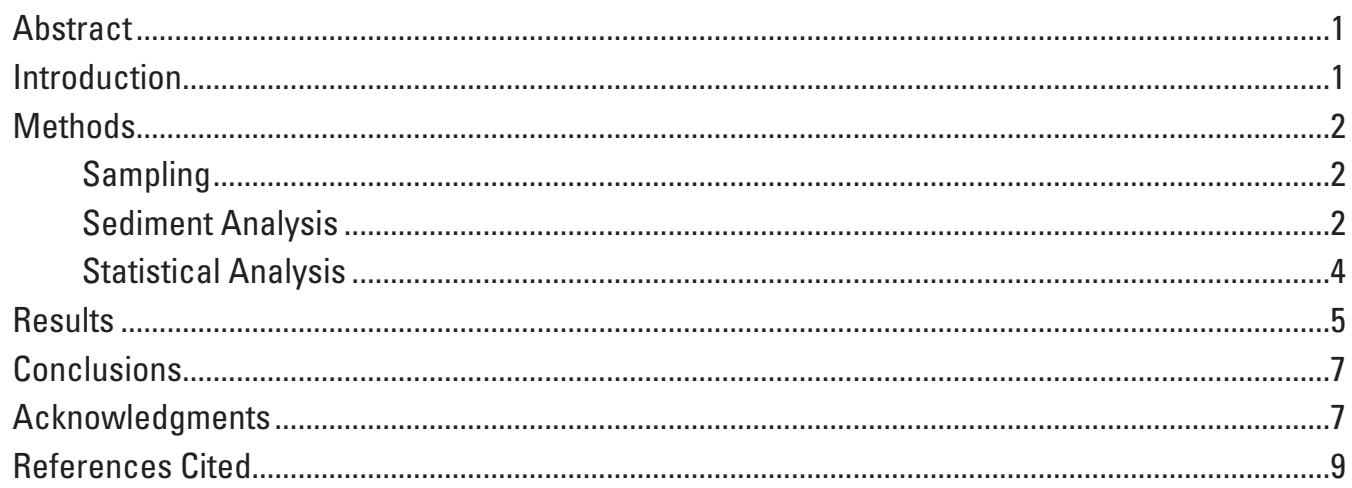

\section{Figures}

1. Graph showing mean ( \pm 1 standard error) macrofaunal densities in sediments from cores collected at stations within each of the five Gulf Coast States ..................6

2. Graph showing percent composition based on macrofaunal densities from cores collected at stations within each of the five Gulf Coast States ..........................

3. Diagram showing cluster analysis of all sites excluding cores that lacked macroinvertebrates .............................................................................................

\section{Tables}

1. USGS Gulf of Mexico sites where samples were taken prior to landfall of the 2010 oil spill .....................................................................................

2. Invertebrate taxa collected in the five Gulf Coast States....................................................

3. Mean ( \pm 1 standard error) macrofaunal abundance, taxon richness, Pielou's evenness, and Shannon-Wiener diversity index for the five Gulf Coast States ..............................................................................................

\section{Appendices}

Appendix 1. Macrofaunal abundance, taxon richness, Pielou's evenness, and Shannon-Wiener diversity index for samples from the five Gulf Coast States. . .10

Appendix 2. Descriptive statistics for benthic community metrics from samples taken prior to oil spill impact for the five Gulf Coast States 



\title{
Benthic Community Structure and Composition in Sediment from the Northern Gulf of Mexico Shoreline, Texas to Florida
}

\author{
By Amanda W.J. Demopoulos' and Douglas G. Strom²
}

\section{Abstract}

From April 20 through July 15, 2010, approximately 4.93 million barrels of crude oil spilled into the Gulf of Mexico from the British Petroleum Macondo-1 well, representing the largest spill in U.S. waters. Baseline benthic community conditions were assessed from shoreline sediment samples collected from 56 stations within the swash zone (for example, sample depth ranged from 0 to 1.5 feet) along the northern Gulf of Mexico coastline. These sites were selected because they had a high probability of being impacted by the oil. Cores collected at 24 stations contained no sediment infauna. Benthic community metrics varied greatly among the remaining stations. Mississippi stations had the highest mean abundances ( $38.9 \pm 23.9$ individuals per 32 square centimeters $\left(\mathrm{cm}^{2}\right)$; range: 0 to 186$)$, while Texas had the lowest abundances, $4.9 \pm 3$ individuals per $32 \mathrm{~cm}^{2}$ (range: 0 to 25 ). Dominant phyla included Annelida, Arthropoda, and Mollusca, but proportional contributions of each group varied by State. Diversity indices Margalef's richness (d) and ShannonWiener diversity (H') were highest at Louisiana and Mississippi stations ( 0.4 and 0.4 , for both, respectively) and lowest at Texas (values for both indices were $0.1 \pm 0.1$ ). Evenness ( $\mathrm{J}^{\prime}$ ) was low for all the States, ranging from 0.2 to 0.3 , indicating a high degree of patchiness at these sites. Across stations within a State, average similarity ranged from 11.1 percent (Mississippi) to 41.1 percent (Louisiana). Low within-state similarity may be a consequence of differing habitat and physical environment conditions. Results provide necessary baseline information that will facilitate future comparisons with postspill community metrics.

\footnotetext{
U.S. Geological Survey, Gainesville, Florida.

${ }^{2}$ Water \& Air Research, Inc. Gainesville, Florida
}

\section{Introduction}

From April 20 through July 15, 2010, approximately 4.93 million barrels of crude oil spilled into the Gulf of Mexico (GOM) from the British Petroleum (BP) Macondo-1 (M1) well (Operational Science Advisory Team, 2010), exceeding any previous oil spills in U.S. waters, as referenced by Wolfe and others (1994) and Bence and others (1996). Chemical dispersants (1.84 million gallons) were applied to the surface oil and at the well head. In response to the potential threat of oil and dispersants to sensitive habitat along the shores of the GOM, the U.S. Geological Survey (USGS) collected nearsurface beach and coastal sediment along the shores of the northern GOM (nGOM) from Texas to Florida before oil made landfall. Selected sites represented wetlands, shorelines, and barrier islands. The purpose of this study was to document baseline benthic infaunal community conditions before the oil made landfall.

Monitoring of macrobenthic communities is important for oil spill impact assessments because benthic invertebrates have relatively long and stable lifespans, they respond quickly to stress, they are vulnerable to the effects of sediment contamination, and they assimilate contaminants over time (Gray and others, 1990; Kingston, 1992; Dauer, 1993). The effects of oil pollution on macrobenthic communities, including those in the GOM, have been extensively reported in the literature (Cabioch and others, 1978; Sanders and others, 1980; Gray and others, 1990; Rakocinski and others, 1998), emphasizing the importance of establishing pre-oil spill impact baseline conditions for impact assessment studies.

This study complements research conducted by other USGS scientists examining sediments and water samples for oil, trace metals, dispersant (Corexit ${ }^{\mathrm{TM}}$ surfactants), organic carbon characterization, bacterial populations responsible for oil degradation, nutrients, and toxicity of pore water collected from the same stations (Wilde and others, 2010). A site map of the sampling locations is given in Wilde and others (2010). 


\section{Methods}

\section{Sampling}

Pre-oil spill sediment samples were collected using a polycarbonate tube core $(6.5$-centimeter $(\mathrm{cm})$ diameter) inserted into the sediment to a depth of $5 \mathrm{~cm}$, and the material was placed into pre-labeled plastic bags prior to freezing. Benthic community sampling was conducted at 56 sites distributed in Texas (10 sites), Louisiana (15 sites), Mississippi (9 sites), Alabama (10 sites), and Florida (12 sites), including beaches (41 sites) and wetland (15 sites) habitats (table 1).

\section{Sediment Analysis}

Sediments were frozen immediately after collection. In the lab, thawed sediments were sieved through a 0.5 -millimeter $(\mathrm{mm})$ mesh sieve to remove fine sediment. Benthic macroinvertebrates were sorted under a dissecting microscope, identified, enumerated, and placed into vials containing 70 percent ethanol so that the material could be retained as preserved vouchers.

Table 1. USGS Gulf of Mexico sites where samples were taken prior to landfall of the 2010 oil spill.

[Map no., map number as defined in Wilde and others (2010); ID, station identification number; BLM, Bureau of Land Management]

\begin{tabular}{|c|c|c|c|c|c|c|}
\hline Map no. & Station ID & Site Name & $\begin{array}{c}\text { Latitude } \\
\text { (decimal degrees) }\end{array}$ & $\begin{array}{c}\text { Longitude } \\
\text { (decimal degrees) }\end{array}$ & $\begin{array}{l}\text { Sample Date: } \\
\text { Pre-Landfall }\end{array}$ & Habitat \\
\hline \multicolumn{7}{|l|}{ TEXAS } \\
\hline TX-47 & 294057093572301 & Texas Point & 29.682500 & -93.956389 & $5 / 10 / 10$ & sand \\
\hline TX-48 & 295542093521701 & Sabine Lake & 29.928333 & -93.871389 & $5 / 10 / 10$ & sand \\
\hline TX-49 & 293324094220601 & High Island & 29.556667 & -94.368333 & $5 / 10 / 10$ & sand \\
\hline TX-50 & 293429094332101 & $\begin{array}{c}\text { East Bay near } \\
\text { Anahuac }\end{array}$ & 29.574722 & -94.555833 & $5 / 10 / 10$ & marsh \\
\hline TX-51 & 291815094461001 & Galveston Island & 29.304167 & -94.769444 & $5 / 10 / 10$ & sand \\
\hline TX-52 & 294408094501101 & $\begin{array}{l}\text { Trinity Bay near } \\
\text { Beach City }\end{array}$ & 29.735556 & -94.836389 & $5 / 11 / 10$ & marsh \\
\hline TX-53 & 292318094430901 & Bolivar Peninsula & 29.388333 & -94.719167 & $5 / 11 / 10$ & sand \\
\hline TX-54 & 292937094544001 & $\begin{array}{l}\text { Galveston Bay near } \\
\text { Eagle Point }\end{array}$ & 29.493611 & -94.911111 & $5 / 11 / 10$ & sand \\
\hline TX-55 & 291251094571401 & $\begin{array}{l}\text { West Bay, Galves- } \\
\text { ton Island State } \\
\text { Park }\end{array}$ & 29.214167 & -94.953889 & $5 / 11 / 10$ & marsh \\
\hline TX-56 & 290512095063101 & San Luis Pass & 29.086667 & -95.108611 & $5 / 11 / 10$ & sand \\
\hline \multicolumn{7}{|c|}{ LOUISIANA } \\
\hline LA-22 & 294432090083100 & $\begin{array}{c}\text { Jean Lafitte } \mathrm{Na}- \\
\text { tional Park }\end{array}$ & 29.742222 & -90.141944 & $5 / 14 / 10$ & marsh \\
\hline LA-23 & 294406091511300 & Cypremort Point & 29.735000 & -91.853611 & $5 / 13 / 10$ & sand \\
\hline LA-24 & 292046090254500 & Lake Felicity & 29.346111 & -90.429167 & $5 / 18 / 10$ & marsh \\
\hline LA-25 & 293808092460200 & $\begin{array}{l}\text { Rockefeller Refuge } \\
\text { Beach }\end{array}$ & 29.635556 & -92.767222 & $5 / 13 / 10$ & marsh \\
\hline LA-26 & 291507090551800 & Sister Lake & 29.251944 & -90.921667 & $5 / 17 / 10$ & sand \\
\hline LA-28 & 293424091321600 & Point Chevreuil & 29.573333 & -91.537778 & $5 / 13 / 10$ & marsh \\
\hline LA-29 & 294324089432500 & Crooked Bayou & 29.723333 & -89.723611 & $5 / 18 / 10$ & marsh \\
\hline LA-30 & 294108089234500 & $\begin{array}{l}\text { Mississippi River } \\
\text { Gulf Outlet }\end{array}$ & 29.685556 & -89.395833 & $5 / 7 / 10$ & sand \\
\hline
\end{tabular}


Table 1. USGS Gulf of Mexico sites where samples were taken prior to landfall of the 2010 oil spill. —Continued [Map no., map number as defined in Wilde and others (2010); ID, station identification number; BLM, Bureau of Land Management]

\begin{tabular}{|c|c|c|c|c|c|c|}
\hline Map no. & Station ID & Site Name & $\begin{array}{c}\text { Latitude } \\
\text { (decimal degrees) }\end{array}$ & $\begin{array}{c}\text { Longitude } \\
\text { (decimal degrees) }\end{array}$ & $\begin{array}{l}\text { Sample Date: } \\
\text { Pre-Landfall }\end{array}$ & Habitat \\
\hline \multicolumn{7}{|c|}{ LOUISIANA - Continued } \\
\hline LA-31 & 291537089570100 & $\begin{array}{l}\text { Grand Isle Beach at } \\
\text { State Park }\end{array}$ & 29.260278 & -89.950278 & $5 / 10 / 10$ & sand \\
\hline LA-32 & 291914089105500 & $\begin{array}{l}\text { Mississippi River at } \\
\text { Main Pass }\end{array}$ & 29.320556 & -89.181944 & $5 / 7 / 10$ & marsh \\
\hline LA-33 & 293518089364300 & Breton Sound & 29.588333 & -89.611944 & $5 / 7 / 10$ & marsh \\
\hline LA-34 & 300907089144500 & $\begin{array}{l}\text { Mississippi Sound } \\
\text { at Grand Pass }\end{array}$ & 30.151944 & -89.245833 & $5 / 7 / 10$ & marsh \\
\hline LA-35 & 285951089085600 & $\begin{array}{l}\text { Mississippi River at } \\
\text { South Pass }\end{array}$ & 28.997500 & -89.148889 & $5 / 7 / 10$ & sand \\
\hline LA-36 & 285615089235600 & $\begin{array}{l}\text { Mississippi River at } \\
\text { Southwest Pass }\end{array}$ & 28.937500 & -89.398889 & $5 / 7 / 10$ & sand \\
\hline LA-46 & 294456093394801 & East Sabine & 29.748889 & -93.663333 & $5 / 10 / 10$ & sand \\
\hline \multicolumn{7}{|c|}{ MISSISSIPPI } \\
\hline MS-37 & 301309089044700 & $\begin{array}{l}\text { South Cat Island } \\
\text { Beach }\end{array}$ & 30.219167 & -89.079722 & $5 / 7 / 10$ & sand \\
\hline MS-38 & 301227088582000 & $\begin{array}{l}\text { West Ship Island } \\
\text { Beach }\end{array}$ & 30.207500 & -88.972222 & $5 / 7 / 10$ & sand \\
\hline MS-39 & 301358088533300 & $\begin{array}{l}\text { East Ship Island } \\
\text { Beach }\end{array}$ & 30.232778 & -88.892500 & $5 / 7 / 10$ & sand \\
\hline $\mathrm{MS}-40$ & 301425088440600 & $\begin{array}{l}\text { West Horn Island } \\
\text { Beach }\end{array}$ & 30.240278 & -88.735000 & $5 / 8 / 10$ & sand \\
\hline MS-41 & 301321088353300 & $\begin{array}{l}\text { East Horn Island } \\
\text { Beach }\end{array}$ & 30.222500 & -88.592500 & $5 / 8 / 10$ & sand \\
\hline MS-42 & 301208088253600 & $\begin{array}{l}\text { Petit Bois Island } \\
\text { Beach }\end{array}$ & 30.202222 & -88.426667 & $5 / 8 / 10$ & sand \\
\hline MS-43 & 301858089141000 & $\begin{array}{l}\text { Pass Christian } \\
\text { Beach }\end{array}$ & 30.316111 & -89.236111 & $5 / 8 / 10$ & sand \\
\hline MS-44 & 302336088535800 & Biloxi Beach & 30.393333 & -88.899444 & $5 / 8 / 10$ & sand \\
\hline MS-45 & 302034088325200 & Pascagoula Beach & 30.342778 & -88.547778 & $5 / 8 / 10$ & sand \\
\hline \multicolumn{7}{|l|}{ ALABAMA } \\
\hline AL-1 & 301338088193500 & $\begin{array}{l}\text { West Dauphin } \\
\text { Island }\end{array}$ & 30.227425 & -88.326394 & $5 / 8 / 10$ & sand \\
\hline AL-2 & 301455088110300 & Dauphin Island & 30.248815 & -88.184168 & $5 / 9 / 10$ & sand \\
\hline AL-3 & 301448088044000 & Dauphin Island & 30.246870 & -88.077777 & $5 / 9 / 10$ & sand \\
\hline AL-4 & 301329088003000 & Fort Morgan & 30.224926 & -88.008330 & $5 / 8 / 10$ & sand \\
\hline AL-5 & 301349087541600 & Fort Morgan & 30.230481 & -87.904438 & $5 / 8 / 10$ & sand \\
\hline AL-6 & 301428087434900 & Gulf Shores & 30.241314 & -87.730265 & $5 / 8 / 10$ & sand \\
\hline AL-7 & 301608087345400 & Orange Beach & 30.269091 & -87.581649 & $5 / 8 / 10$ & sand \\
\hline AL-8 & 301353087561600 & BLM-1 & 30.231593 & -87.937772 & $5 / 24 / 10$ & sand \\
\hline AL-9 & 301343087520200 & BLM-2 & 30.228815 & -87.867214 & $5 / 24 / 10$ & sand \\
\hline AL-10 & 301341087495200 & $\begin{array}{l}\text { Fort Morgan } \\
\text { BLM-3 }\end{array}$ & 30.228259 & -87.831102 & $5 / 24 / 10$ & sand \\
\hline
\end{tabular}


Table 1. USGS Gulf of Mexico sites where samples were taken prior to landfall of the 2010 oil spill. —Continued

[Map no., map number as defined in Wilde and others (2010); ID, station identification number; BLM, Bureau of Land Management]

\begin{tabular}{|c|c|c|c|c|c|c|}
\hline Map no. & Station ID & Site Name & $\begin{array}{c}\text { Latitude } \\
\text { (decimal degrees) }\end{array}$ & $\begin{array}{c}\text { Longitude } \\
\text { (decimal degrees) }\end{array}$ & $\begin{array}{l}\text { Sample Date: } \\
\text { Pre-Landfall }\end{array}$ & Habitat \\
\hline \multicolumn{7}{|l|}{ FLORIDA } \\
\hline FL-2 & 302258086263400 & $\begin{array}{l}\text { Henderson Beach } \\
\text { State Park near } \\
\text { Destin }\end{array}$ & 30.382944 & -86.442778 & $5 / 11 / 10$ & sand \\
\hline FL-4 & 300729085440900 & $\begin{array}{l}\text { St. Andrews } \\
\text { State Park near } \\
\text { Panama City }\end{array}$ & 30.124722 & -85.736028 & $5 / 12 / 10$ & sand \\
\hline FL-6 & 294152084460300 & $\begin{array}{l}\text { St George Island } \\
\text { State Park near } \\
\text { East Point }\end{array}$ & 29.697861 & -84.767750 & $5 / 13 / 10$ & sand \\
\hline FL-15 & 254002080092000 & $\begin{array}{l}\text { Bill Baggs Cape } \\
\text { near Key Bis- } \\
\text { cayne }\end{array}$ & 25.667417 & -80.155528 & $6 / 1 / 10$ & sand \\
\hline FL-21 & 243902081332700 & $\begin{array}{l}\text { BLM Tract1 near } \\
\text { Park Key }\end{array}$ & 24.650556 & -81.557500 & $6 / 9 / 10$ & marsh \\
\hline FL-26 & 244325081351500 & $\begin{array}{l}\text { Marvin Key at } \\
\text { Great White } \\
\text { Heron National } \\
\text { Wildlife Refuge }\end{array}$ & 24.709806 & -81.644639 & $7 / 7 / 10$ & marsh \\
\hline
\end{tabular}

\section{Statistical Analysis}

Conventional statistical analyses were performed using MINITAB version 16.2.1. Metrics from datasets with and without zero-abundance samples were tested for significant differences of the means among States with analysis of variance (ANOVA) after testing the data for normality and equality of variances. Medians of the metrics from the same datasets were tested using the Mann-Whitney test, the Kruskal-Wallis test, and the Mood's Median test. A p-level of 0.05 was used as the criterion for statistical significance.

Macrofaunal diversity was examined with PRIMER Statistical Software version 6.1.8 (Clark and Gorley, 2006) using species richness ( $\mathrm{S}$, number of species), normalized species richness per core (Margalef's $d=S-1 / \ln (N)$, where $\mathrm{N}$ is the number of individuals), Shannon-Wiener index (H', log base 2), and evenness (J') per core. Similarities and differences in macrofaunal communities were examined using hierarchical cluster analysis and nonmetric multidimensional scaling (MDS) ordination, based on Bray-Curtis similarity indices. MDS ordination was performed with the Kruskal fit scheme 1; 1,000 restarts were performed, and the minimum stress level was set to 0.01 . The PRIMER one-way ANOSIM procedure was performed to test for differences among States and habitats (sand versus marsh). In addition, a two-way nested design was used, with habitats nested within States. 
The PRIMER SIMPER procedure was applied to determine those taxa that contributed most to the significant differences among groups tested when ANOSIM found significant differences between groups. Values of the ANOSIM $r$ statistic were calculated for the global test between groups, also known as the Global $r$. The cut-off percentage was set at 80 percent for these analyses. These taxa were tabulated for the significant comparisons among States.

Initially, all data were included in statistical analyses, including data from 24 stations for which no organisms were recovered upon sorting. Alabama had the fewest samples without organisms (1); Mississippi had 4, Florida and Texas both had 5, and Louisiana had 9 samples containing 0 organisms. Because inclusion of these samples can inappropriately assign similarities to samples with zero-abundance data for no legitimate reason (Clark and Warwick, 2001), samples containing no macroinvertebrates were excluded from the similarity matrix, MDS, and ANOSIM analyses. At stations FL-6, FL-16, FL-21, AL-2, LA-23, LA-31, MS-45, and TX-51 multiple core samples were collected within a station and therefore were considered pseudoreplicates. Statistical analysis of pseudoreplicates was treated as follows: average values were calculated for macrofaunal abundance, diversity, and evenness, and these averages were used for the site data in the overall PRIMER analysis (ANOSIM, Cluster, Bray-Curtis similarities). In addition, within stations, small scale variability was calculated from these pseudoreplicates.

\section{Results}

Thirty-three macroinvertebrate taxa were identified in the study collections (table 2). Mean abundances of benthic invertebrates were greatest at the Mississippi stations (table 3, fig. $1,38.9 \pm 23.9$ individuals per $32 \mathrm{~cm}^{2}$, range: 0 to 186 ), while Texas had the lowest abundances, $4.9 \pm 3$ individuals per $32 \mathrm{~cm}^{2}$ (range: 0 to 25). There was a great deal of variation in the abundance data among and within sites, several having zero taxa in each core (appendix 1). Communities were composed of Annelida, Arthropoda, and Mollusca, but proportional contributions of each group varied by State (fig. 2). Number of taxa per core ranged from 0 to 12 (appendix 1). Margalef's richness (d) and Shannon-Wiener diversity (H') were highest at Louisiana and Mississippi stations and lowest at Texas sites $(0.1 \pm 0.1$, table 3$)$. Evenness (J') was low for all the States, ranging from 0.2 to 0.3 .

Descriptive statistics are presented for metrics in total and among States from datasets with and without zero-abundance samples in appendix 2. For the dataset including zero-abundance samples, no significant differences were found for the means and the medians. Data were not normally distributed, and results for the tests for equal variances were mixed. When zero-value samples were excluded from the data, the distributions became generally closer to normality. None of the comparisons of the medians for this dataset were significant. It is
Table 2. Invertebrate taxa collected in the five Gulf Coast States.

[LPIL, lowest practicable identification level]

\begin{tabular}{|c|c|}
\hline Phylum & Taxonomic Identification \\
\hline \multirow[t]{7}{*}{ Annelida } & Heteromastus filiformis \\
\hline & Orbiniidae (LPIL) \\
\hline & Scoloplos texana \\
\hline & Neanthes succinea \\
\hline & Nereididae (LPIL) \\
\hline & Hypereteone heteropoda \\
\hline & Spionidae (LPIL) \\
\hline \multirow[t]{21}{*}{ Arthropoda } & Apocorophium louisianum \\
\hline & Gammarus mucronatus \\
\hline & Haustorius jayneae \\
\hline & Parhyale hawaiensis \\
\hline & Cerapus benthophilus \\
\hline & Cerapus sp. \\
\hline & Elasmopus cf. rapax Foster \\
\hline & Elasmopus sp. \\
\hline & Amphipoda (LPIL) \\
\hline & Cyclaspis varians \\
\hline & Spilocuma salomani \\
\hline & Oxyurostylis smithi \\
\hline & Emerita talpoida \\
\hline & Palaemonetes sp. \\
\hline & Sesarma reticulatum \\
\hline & Cirolana parva \\
\hline & Edotia triloba \\
\hline & Exosphaeroma productatelson \\
\hline & Balanus sp. \\
\hline & Chthamalus fragilis \\
\hline & Ephemerellidae (LPIL) \\
\hline \multirow[t]{5}{*}{ Mollusca } & Micromenetus dilatatus \\
\hline & Hydrobiidae (LPIL) \\
\hline & Amygdalum papyrium \\
\hline & Mytilidae (LPIL) \\
\hline & Donax variabilis \\
\hline
\end{tabular}

suggested that this result was due to the preponderance of low values for most metrics, and the resultant left-side skewing of the data resulted in similar medians for each metric that were not significantly different from each other. Mean abundance was found to be significantly higher for Mississippi versus mean abundance for all the other States ( $\mathrm{p}=0.02$, one-way ANOVA with Tukey's method and Hsu's Multiple Comparison tests applied). Because there was considerable overlap for all the other metrics, no attempt was made to transform the data. (All raw statistical data outputs are available from the authors.) 
Table 3. Mean ( \pm 1 standard error) macrofaunal abundance, taxon richness (S and Margalef's d), Pielou's evenness (J'), and ShannonWiener diversity index $\left(\mathrm{H}^{\prime}\right)$ for samples from the five Gulf Coast States.

$\left[\mathrm{N}\right.$, total number of samples collected; $\mathrm{S}$, number of species per core $\left(32 \mathrm{~cm}^{2}\right) ; \mathrm{d}=$ Margalef's $\mathrm{d}=\mathrm{S}-1 / \log \left(\right.$ Abundance) $=\mathrm{S}-1 / \log \left(\#\right.$ individuals per $\left.32 \mathrm{~cm}{ }^{2}\right)$; $\mathrm{cm}^{2}$ - square centimeters]

\begin{tabular}{|c|c|c|c|c|c|c|}
\hline State & $\mathbf{N}$ & $\begin{array}{l}\text { Abundance } \\
\left(\# / 32 \mathrm{~cm}^{2}\right)\end{array}$ & S & d & $\mathbf{J}^{\prime}$ & $\mathrm{H}^{\prime}$ \\
\hline Texas & 10 & $4.9 \pm 3.0$ & $0.7 \pm 0.3$ & $0.1 \pm 0.0$ & $0.2 \pm 0.1$ & $0.1 \pm 0.1$ \\
\hline Mississippi & 9 & $38.9 \pm 23.9$ & $2.1 \pm 1.3$ & $0.4 \pm 0.2$ & $0.3 \pm 0.1$ & $0.4 \pm 0.2$ \\
\hline Alabama & 10 & $9.1 \pm 3.6$ & $1.3 \pm 0.3$ & $0.2 \pm 0.1$ & $0.2 \pm 0.1$ & $0.2 \pm 0.1$ \\
\hline
\end{tabular}

Figure 1. Mean ( \pm 1 standard error) macrofaunal densities in sediments from cores collected at stations within each of the five Gulf Coast States. Mean abundance for Mississippi was significantly higher than mean abundance for all the other States $(p=0.02$, one-way ANOVA with Tukey's method and Hsu's Multiple Comparison tests applied post hoc).
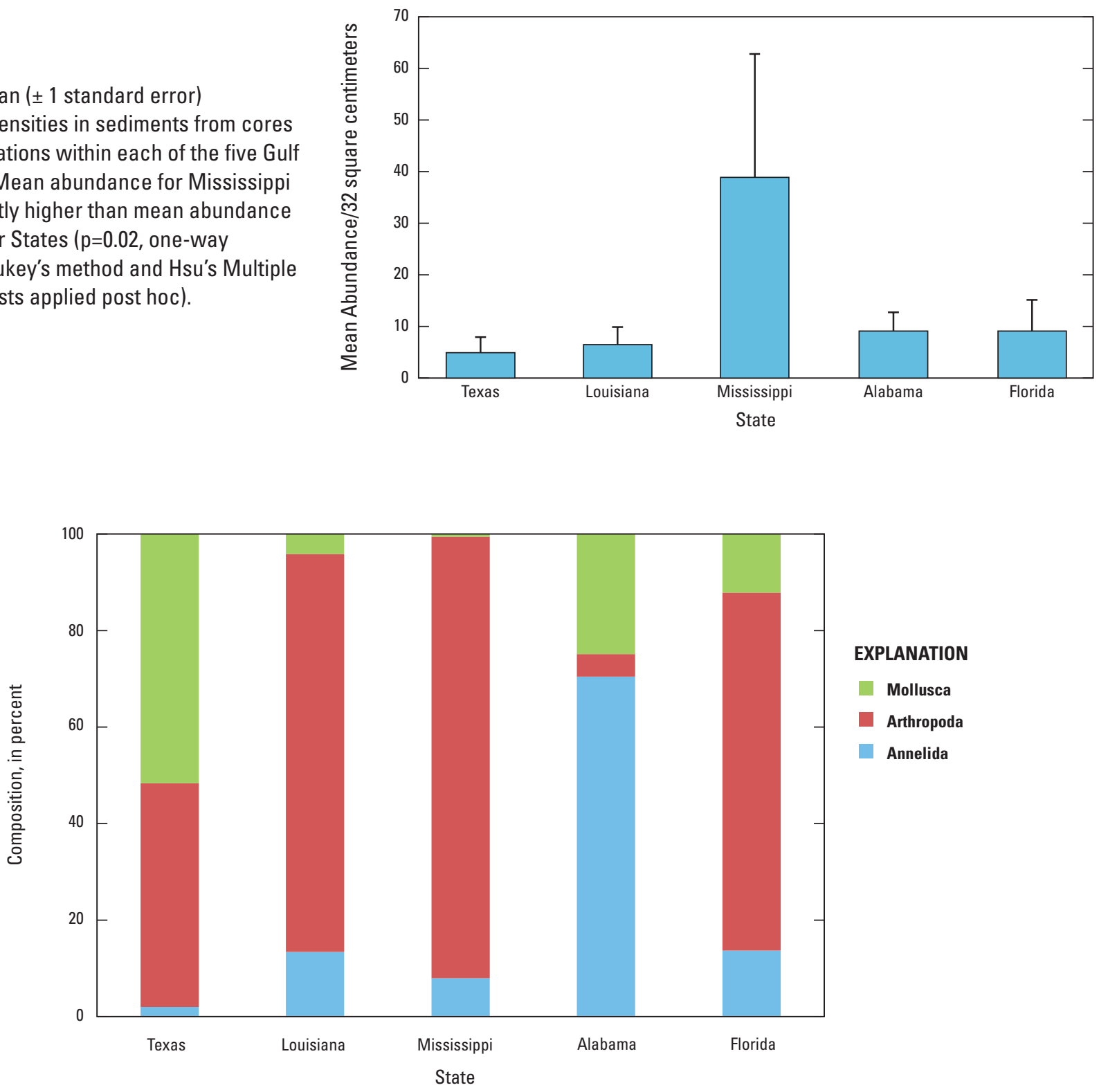

Figure 2. Percent composition based on macrofaunal densities from cores collected at stations within each of the five Gulf Coast States. 
Average similarity among stations within each State ranged from 11.1 percent (Mississippi) to 41.1 percent (Louisiana). Low among-station similarity within States suggests high variability in benthic community composition, possibly a result of among-station differences in physical conditions including wave exposure and salinity (Rakocinski and others, 1998). Clear groupings by habitat were observed in the cluster analysis for the following sites: FL-26, LA-24, LA-33, and LA-34 (fig. 3). While ANOSIM comparisons of the macrofaunal assemblages were significant when using State (Global $\mathrm{r}=0.154, \mathrm{p}=0.005)$ and habitat (Global $\mathrm{r}=0.335, \mathrm{p}=0.001)$ as a factor, the low Global $r$ value $(<0.4)$ indicates that separation between groups (States or habitats) is small. However, when habitats (marsh, sand) were nested within States, ANOSIM was significant, (Global $r=0.688, p=0.002$ ) and the high Global $r$ indicates that there is a large separation among groups. Overall, the sand group had higher abundances of the amphipod Haustorius jayneae and the clam Donax variabilis, whereas the marsh group had higher abundances of the isopod Cirolana parva and the polychaete Heteromastus filiformis, representing 50 percent of community differences observed. FL-7 and TX-52 were two marsh sites distinct from the others (fig. 3), due to the presence of different organisms (Heteromastus filiformis and the polychaete Hypereteone heteropoda for FL-7) and unidentified polychaetes of the family Nereididae (TX-52). Station FL-7 represented a mixture of sand and marsh habitat, and this habitat heterogeneity may have been responsible for the community differences observed. Several stations in Alabama clustered together (fig. 3, AL-4, 5, 6, 7, 8), all due to the presence of unidentified Spionidae polychaetes.

Analysis of pseudoreplicate cores yielded insight into small scale variability in the benthic communities at a subset of stations. Cores from stations AL-2, FL-6, LA-31, and TX-51 produced non-zero-abundance data, and similarity was the highest among pseudoreplicate cores collected from TX-51 (67.4 percent similarity) and lowest for FL-6 (26.2 percent). Results suggest a great degree of within-station, small-scale $(<1$ meter) spatial heterogeneity in the benthic communities.

\section{Conclusions}

Various physical factors can influence the structure of nearshore macrobenthic communities, including wave disturbance, sediment transport, changes in temperature, and salinity (Rakocinski and others, 1998; McLachlan and Brown, 2006), resulting in distinct sandy-shore assemblages (Rakocinski and others, 1991). Macrobenthic responses to these physical factors, including changes in density, diversity, composition, and dominance, also vary across different spatial scales, from meters to regional levels (Morrisey and others, 1992). Dominant organisms may be distributed in patches or aggregations where density is very high, adjacent to areas with few individuals. These aggregations may be physically or behaviorally mediated (McLachlan and Brown, 2006).

Sediment samples were collected at 56 stations along the northern Gulf of Mexico coastline for benthic community analysis prior to oil reaching landfall. Twenty-four out of 64 cores had 0 infauna. MDS and cluster analysis of the cores with non-zero-abundance data revealed distinct groupings, particularly by habitat. Macrofaunal densities and diversity patterns were consistent with those published from Gulf of Mexico beaches (Rakocinski and others 1991; 1998). Differences in macrobenthic metrics observed within States across stations in this study may be related to different physical conditions present and the macrobenthic response at each of the stations sampled. Although this report did not address sediment chemistry, chemical factors can also influence the structure and abundance of benthic organisms. Results of this study provide the critical baseline information for future comparisons with post-oil spill community metrics.

\section{Acknowledgments}

USGS pre-oil spill impact collections and analyses were initiated by the USGS and later funded by the U.S. Coast Guard. We thank A. Strong and J. Frometa for logistical support within the Demopoulos lab. 


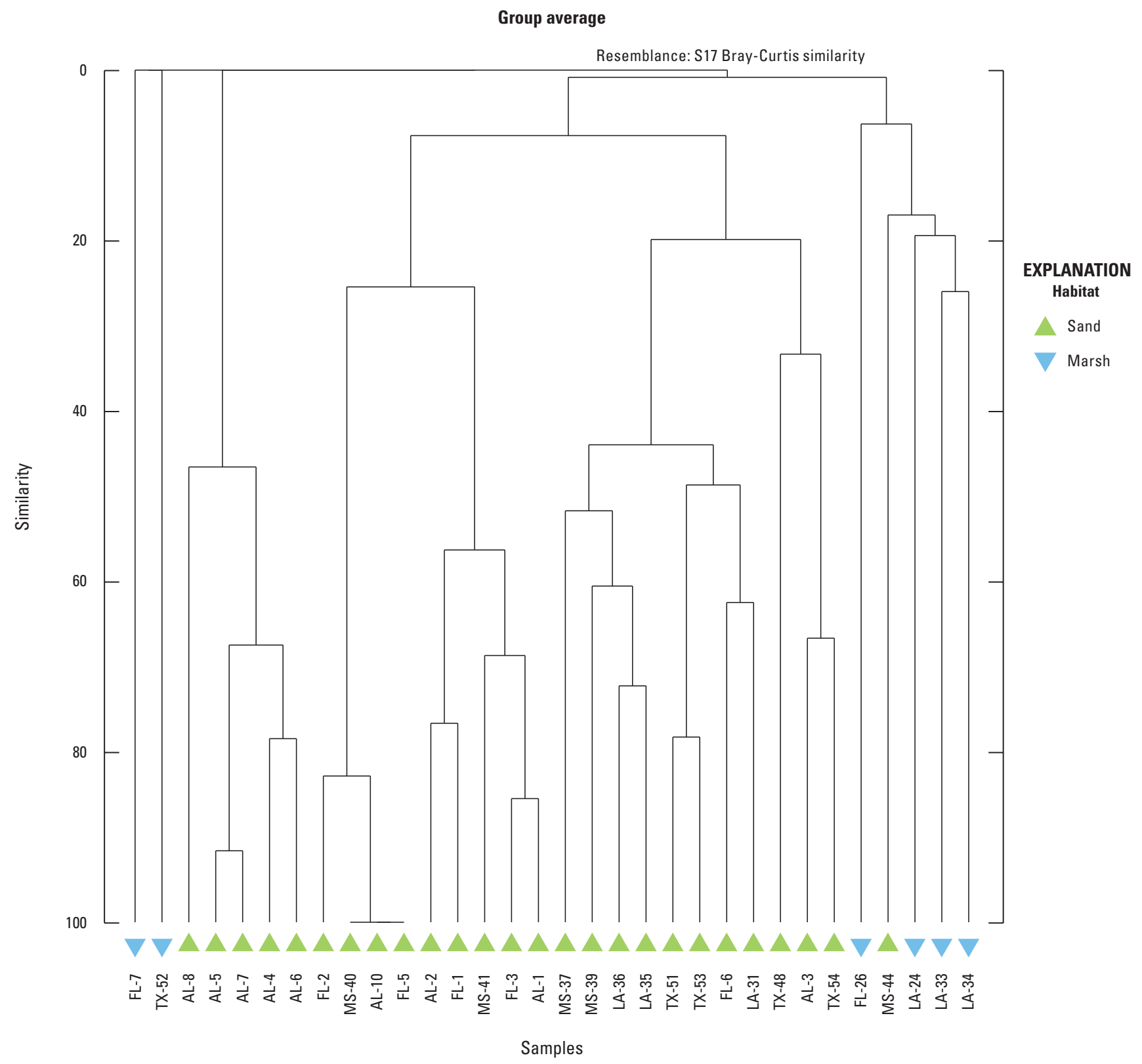

Figure 3. Cluster analysis of all sites excluding cores that lacked macroinvertebrates. 


\section{References Cited}

Bence, A.E., Kvenvolden, K.A., and Kennicutt, M.C., II, 1996, Organic geochemistry applied to environmental assessments of Prince William Sound, Alaska, after the Exxon Valdez oil spill-a review: Organic Geochemistry, v. 24, p. 7-42.

Cabioch, L., Dauvin, J.C., and Gentill, F., 1978, Preliminary observations on pollution of the sea bed and disturbance of sub-littoral communities in northern Brittany by oil from Amoco Cadiz: Marine Pollution Bulletin, 9, p. 303-307.

Clark, K.R., and Gorley, R.N., 2006, Primer v6: User manual/tutorial: Plymouth, England, Primer-E Limited.

Clarke, K.R., and Warwick, R.M., 2001, Change in marine communities: an approach to statistical analysis and interpretation, (2d ed.): Plymouth, England, PRIMER-E.

Dauer, D.M., 1993, Biological criteria, environmental health and estuarine macrobenthic community structure: Marine Pollution Bulletin, v. 26, p. 249-257.

Gray, J.S., Clarke, K.R., Warwick, R.M., and Hobbs, G., 1990, Detection of initial effects of pollution on marine benthos: an example from the Ekofisk and Eldfisk oilfields, North Sea: Marine Ecology Progress Series, v. 66, p. 285-299.

Kingston, P.F., 1992, Impact of offshore oil production installations on the benthos of the North Sea: Journal of Marine Science, v. 49, p. 45-53.

McLachlan, A., and Brown, A.C., 2006, The ecology of sandy shores (2d ed.): Amsterdam, Elsevier, 373 p.

Morrisey, D.J., Howitt, L., Underwood, A.J., and Stark, J.S. 1992, Spatial variation in soft-sediment benthos: Marine Ecology Progress Series, v. 81, p. 197-204.
Operational Science Advisory Team, 2010, Summary report for sub-sea and sub-surface oil and dispersant detection: sampling and monitoring: Prepared for Paul F. Zukunft, RADM, U.S. Coast Guard Federal On-Scene Coordinator, Deepwater Horizon MC252, available at http://www.restorethegulf.gov/sites/default/files/documents/ pdf/OSAT_Report_FINAL_17DEC.pdf.

Rakocinski, C.F., Heard, R.W., Simons, T., and Gledhill, D., 1991, Macrobenthic associations from beaches of selected barrier islands in the northern Gulf of Mexico: Important environmental relationships: Bulletin of Marine Science, v. 48 , p. $689-701$.

Rakocinski, C.F, LeCroy, S.E., McLelland, J.A., and Heard, R.W., 1998, Nested spatiotemporal scales of variation in sandy-shore macrobenthic community structure: Bulletin of Marine Science, v. 63, p. 343-362.

Sanders, H.L., Grassle, J.F., Hampson, G.R., Morse, L.S., Price-Garner, S., and Jones, C.C., 1980, Anatomy of an oil spill: long-term effects from the grounding of the barge Florida off West Falmouth, Massachusetts: Journal of Marine Research, v. 38, p. 265-280.

Wilde, F.D., Skrobialowski, S.C., and Hart, J.S., 2010, Sampling protocol for post-landfall Deepwater Horizon oil release, Gulf of Mexico, 2010: U.S. Geological Survey Open-File Report 2010-1191, 155 p., available at http://pubs.usgs.gov/of/2010/1191/.

Wolfe, D.A., Hameedi, M.J., Galt, J.A., Watabayashi, G., Short, J., O’Clair, C., Rice, S., Michel, J., Payne, J.R., Braddock, J., Hanna, S., and Sale, D., 1994, The fate of the oil spilled from the Exxon Valdez: Environmental Science \& Technology, v. 28 , no. 13 , p. 560A-568A. 
Appendix 1. Macrofaunal abundance, taxon richness ( $S$ and Margalef's d), Pielou's evenness (J'), and Shannon-Wiener diversity index $\left(\mathrm{H}^{\prime}\right)$ for samples from the five Gulf Coast States.

[Map no., map number as defined in Wilde and others (2010); ID, station identification number; S, number of species per core $\left(32 \mathrm{~cm}^{2}\right) ; \mathrm{d}=$ Margalef's $\mathrm{d}=\mathrm{S}-1 / \log$ (Abundance) $=\mathrm{S}-1 / \log \left(\#\right.$ individuals per $\left.32 \mathrm{~cm}^{2}\right)$; $\mathrm{cm}^{2}$, square centimeters]

\begin{tabular}{|c|c|c|c|c|c|c|}
\hline Map no. & Station ID & $\begin{array}{c}\text { Abundance } \\
\left(\# / 32 \mathrm{~cm}^{2}\right)\end{array}$ & S & d & $\mathbf{J}^{\prime}$ & $H^{\prime}\left(\log ^{2}\right)$ \\
\hline \multicolumn{7}{|l|}{ TEXAS } \\
\hline TX-47 & 294057093572301 & 0 & 0 & 0.000 & 0.000 & 0.000 \\
\hline TX-48 & 295542093521701 & 1 & 1 & 0.000 & 0.000 & 0.000 \\
\hline TX-49 & 293324094220601 & 0 & 0 & 0.000 & 0.000 & 0.000 \\
\hline TX-50 & 293429094332101 & 0 & 0 & 0.000 & 0.000 & 0.000 \\
\hline TX-51 & 291815094461001 & 21 & 2 & 0.203 & 0.746 & 0.498 \\
\hline TX-52 & 294408094501101 & 1 & 1 & 0.000 & 0.000 & 0.000 \\
\hline TX-53 & 292318094430901 & 25 & 2 & 0.311 & 0.943 & 0.943 \\
\hline TX-54 & 292937094544001 & 1 & 1 & 0.000 & 0.000 & 0.000 \\
\hline TX-55 & 291251094571401 & 0 & 0 & 0.000 & 0.000 & 0.000 \\
\hline TX-56 & 290512095063101 & 0 & 0 & 0.000 & 0.000 & 0.000 \\
\hline \multicolumn{7}{|c|}{ LOUISIANA } \\
\hline LA-22 & 294432090083100 & 0 & 0 & 0.000 & 0.000 & 0.000 \\
\hline LA-23 & 294406091511300 & 0 & 0 & 0.000 & 0.000 & 0.000 \\
\hline LA-24 & 292046090254500 & 5 & 4 & 1.864 & 0.961 & 1.922 \\
\hline LA-25 & 293808092460200 & 0 & 0 & 0.000 & 0.000 & 0.000 \\
\hline LA-26 & 291507090551800 & 0 & 0 & 0.000 & 0.000 & 0.000 \\
\hline LA-28 & 293424091321600 & 0 & 0 & 0.000 & 0.000 & 0.000 \\
\hline LA-29 & 294324089432500 & 0 & 0 & 0.000 & 0.000 & 0.000 \\
\hline LA-30 & 294108089234500 & 0 & 0 & 0.000 & 0.000 & 0.000 \\
\hline LA-31 & 291537089570100 & 6 & 2 & 0.303 & 0.918 & 0.306 \\
\hline LA-32 & 291914089105500 & 0 & 0 & 0.000 & 0.000 & 0.000 \\
\hline LA-33 & 293518089364300 & 15 & 7 & 2.216 & 0.863 & 2.423 \\
\hline LA-34 & 300907089144500 & 5 & 3 & 1.243 & 0.865 & 1.371 \\
\hline LA-35 & 285951089085600 & 50 & 1 & 0.000 & 0.000 & 0.000 \\
\hline LA-36 & 285615089235600 & 16 & 1 & 0.000 & 0.000 & 0.000 \\
\hline LA-46 & 294456093394801 & 0 & 0 & 0.000 & 0.000 & 0.000 \\
\hline \multicolumn{7}{|c|}{ MISSISSIPPI } \\
\hline MS-37 & 301309089044700 & 141 & 2 & 0.202 & 0.061 & 0.061 \\
\hline MS-38 & 301227088582000 & 0 & 0 & 0.000 & 0.000 & 0.000 \\
\hline MS-39 & 301358088533300 & 19 & 2 & 0.340 & 0.950 & 0.949 \\
\hline MS-40 & 301425088440600 & 1 & 1 & 0.000 & 0.000 & 0.000 \\
\hline MS-41 & 301321088353300 & 3 & 2 & 0.910 & 0.918 & 0.918 \\
\hline MS-42 & 301208088253600 & 0 & 0 & 0.000 & 0.000 & 0.000 \\
\hline MS-43 & 301858089141000 & 0 & 0 & 0.000 & 0.000 & 0.000 \\
\hline MS-44 & 302336088535800 & 186 & 12 & 2.105 & 0.512 & 1.835 \\
\hline MS-45 & 302034088325200 & 0 & 0 & 0.000 & 0.000 & 0.000 \\
\hline
\end{tabular}


Appendix 1. Macrofaunal abundance, taxon richness ( $S$ and Margalef's d), Pielou's evenness (J'), and Shannon-Wiener diversity index $\left(\mathrm{H}^{\prime}\right)$ for samples from the five Gulf Coast States. - Continued

[Map no., map number as defined in Wilde and others (2010); ID, station identification number; S, number of species per core $\left(32 \mathrm{~cm}^{2}\right) ; \mathrm{d}=$ Margalef's $\mathrm{d}=\mathrm{S}-1 / \log$ (Abundance) $=\mathrm{S}-1 / \log \left(\#\right.$ individuals per $\left.32 \mathrm{~cm}^{2}\right)$; $\mathrm{cm}^{2}$, square centimeters]

\begin{tabular}{|c|c|c|c|c|c|c|}
\hline Map no. & Station ID & $\begin{array}{c}\text { Abundance } \\
\left(\# / 32 \mathrm{~cm}^{2}\right)\end{array}$ & $\mathbf{S}$ & d & $\mathbf{J}^{\prime}$ & $H^{\prime}\left(\log ^{2}\right)$ \\
\hline \multicolumn{7}{|l|}{ ALABAMA } \\
\hline AL-1 & 301338088193500 & 20 & 2 & 0.334 & 0.286 & 0.286 \\
\hline AL-2 & 301455088110300 & 4 & 3 & 0.412 & 0.702 & 0.468 \\
\hline AL-3 & 301448088044000 & 2 & 2 & 1.443 & 1.000 & 1.000 \\
\hline AL-4 & 301329088003000 & 15 & 1 & 0.000 & 0.000 & 0.000 \\
\hline AL-5 & 301349087541600 & 5 & 1 & 0.000 & 0.000 & 0.000 \\
\hline AL-6 & 301428087434900 & 36 & 1 & 0.000 & 0.000 & 0.000 \\
\hline AL-7 & 301608087345400 & 7 & 1 & 0.000 & 0.000 & 0.000 \\
\hline AL-8 & 301353087561600 & 1 & 1 & 0.000 & 0.000 & 0.000 \\
\hline AL-9 & 301343087520200 & 0 & 0 & 0.000 & 0.000 & 0.000 \\
\hline AL-10 & 301341087495200 & 1 & 1 & 0.000 & 0.000 & 0.000 \\
\hline \multicolumn{7}{|l|}{ FLORIDA } \\
\hline FL-1 & 302144086581200 & 4 & 1 & 0.000 & 0.000 & 0.000 \\
\hline FL-2 & 302258086263400 & 2 & 1 & 0.000 & 0.000 & 0.000 \\
\hline FL-3 & 301926086091800 & 10 & 2 & 0.434 & 0.469 & 0.469 \\
\hline FL-4 & 300729085440900 & 0 & 0 & 0.000 & 0.000 & 0.000 \\
\hline FL-5 & 294645085243000 & 1 & 1 & 0.000 & 0.000 & 0.000 \\
\hline FL-6 & 294152084460300 & 4 & 3 & 0.257 & 0.592 & 0.197 \\
\hline FL-7 & 300427084105000 & 14 & 3 & 0.758 & 0.597 & 0.946 \\
\hline FL-15 & 254002080092000 & 0 & 0 & 0.000 & 0.000 & 0.000 \\
\hline FL-16 & 260454080063400 & 0 & 0 & 0.000 & 0.000 & 0.000 \\
\hline FL-21 & 243902081332700 & 0 & 0 & 0.000 & 0.000 & 0.000 \\
\hline FL-25 & 300223085260800 & 0 & 0 & 0.000 & 0.000 & 0.000 \\
\hline FL-26 & 244325081351500 & 74 & 4 & 0.697 & 0.317 & 0.635 \\
\hline
\end{tabular}


Appendix 2. Descriptive statistics for benthic community metrics from samples taken prior to oil spill impact for the five Gulf Coast States.

[Variables: N-sample abundance; S - number of taxa; d- Margalef's d Index; J' - Pielou's evenness; H' - Shannon-Wiener Diversity Index base 2. Statistics: $\mathrm{N}$ - number of non-missing records; $\mathrm{N}^{*}$ - number of missing records; SE Mean - standard error of the mean; St Dev - standard deviation; Q1 - first quartile; Q3 - third quartile. TX-Texas; LA-Louisiana; MS-Mississippi; AL-Alabama; FL-Florida.]

Table A1. Descriptive statistics for all state data, combined. Pseudoreplicates are given as separate records and zero-abundance samples are included.

\begin{tabular}{cccccccccccc}
\hline Variable & N & N* $^{*}$ & Mean & SE Mean & StDev & Minimum & Q1 & Median & Q3 & Maximum \\
\hline N & 64 & 0 & 12.00 & 3.83 & 30.60 & 0.00 & 0.00 & 1.50 & 9.50 & 186.00 \\
S & 64 & 0 & 1.250 & 0.231 & 1.852 & 0.000 & 0.000 & 1.000 & 2.000 & 12.000 \\
D & 63 & 1 & 0.2560 & 0.0656 & 0.5209 & 0.0000 & 0.0000 & 0.0000 & 0.3235 & 2.2160 \\
J' & 58 & 6 & 0.2267 & 0.0475 & 0.3620 & 0.0000 & 0.0000 & 0.0000 & 0.5274 & 1.0000 \\
H' & 64 & 0 & 0.2838 & 0.0673 & 0.5384 & 0.0000 & 0.0000 & 0.0000 & 0.5482 & 2.4226 \\
\hline
\end{tabular}

Table A2. Descriptive statistics for all state data, separately. Pseudoreplicates are given as separate records and zero-abundance samples are included.

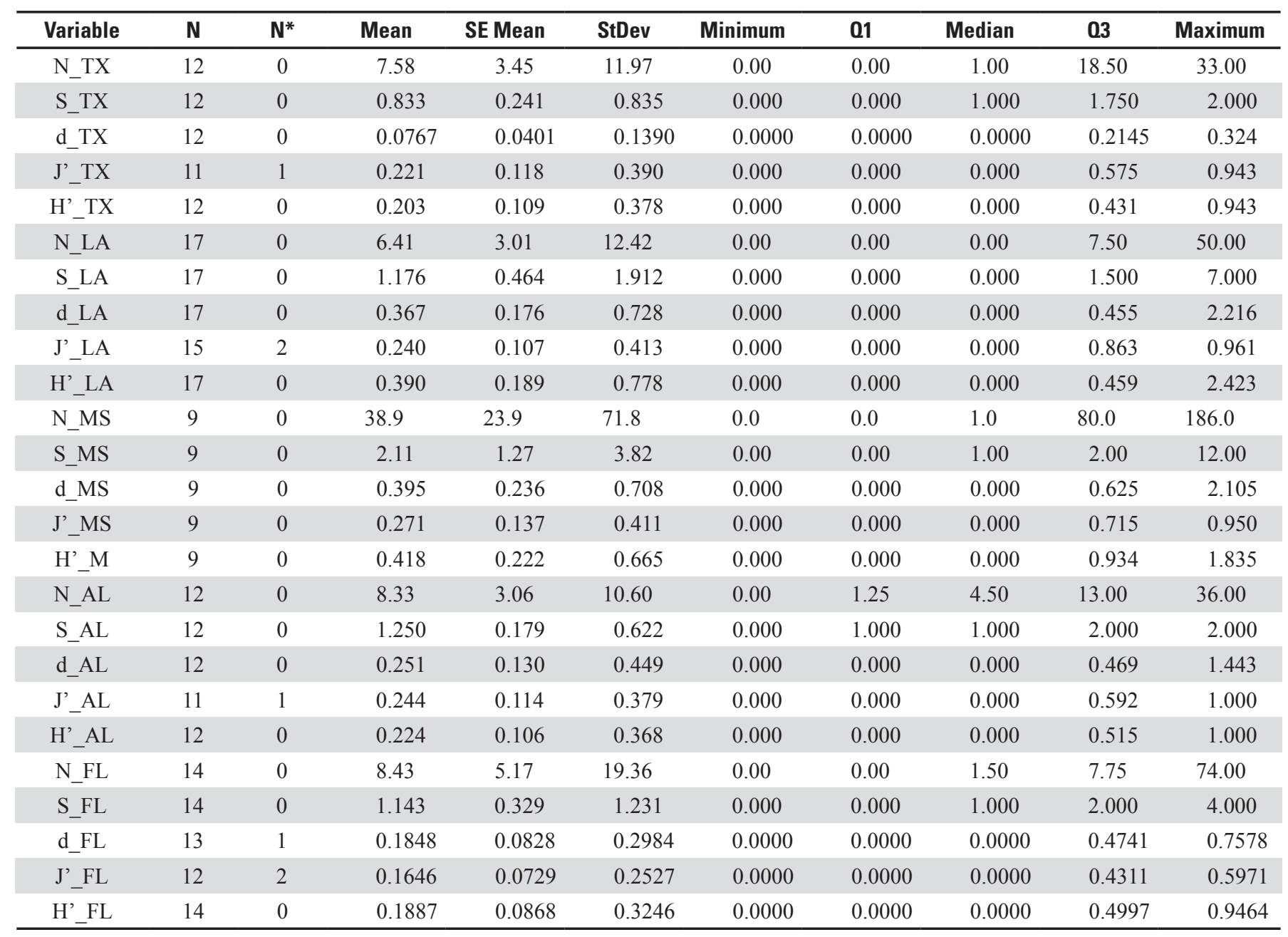


Table A3. Descriptive statistics for all state data, combined. * Pseudoreplicates are given as separate records and zero-abundance samples are excluded.

\begin{tabular}{ccccccccccc}
\hline Variable & N & N $^{*}$ & Mean & SE Mean & StDev & Minimum & Q1 & Median & Q3 & Maximum \\
\hline N_NZ & 40 & 0 & 19.20 & 5.85 & 37.03 & 1.00 & 2.00 & 6.00 & 18.25 & 186.00 \\
S_NZ & 40 & 0 & 2.000 & 0.316 & 2.000 & 1.000 & 1.000 & 1.000 & 2.000 & 12.000 \\
d_NZ & 39 & 1 & 0.4135 & 0.0982 & 0.6130 & 0.0000 & 0.0000 & 0.0000 & 0.6970 & 2.2160 \\
J'_NZ & 34 & 6 & 0.3867 & 0.0692 & 0.4032 & 0.0000 & 0.0000 & 0.3019 & 0.8634 & 1.0000 \\
H'_NZ & 40 & 0 & 0.4541 & 0.0986 & 0.6237 & 0.0000 & 0.0000 & 0.0000 & 0.9183 & 2.4226 \\
\hline
\end{tabular}

*This table and the following summaries excluded zero abundance value sites data. This was done, rather than attempting to transform the raw data including zero value sites to redo the parametric tests, because an examination of the normality plots indicates that the data deviated from normality primarily due to the inclusion of the zero value site data.

Table A4. Descriptive statistics for all state data, separately. Pseudoreplicates are given as separate records and zero-abundance samples are excluded.

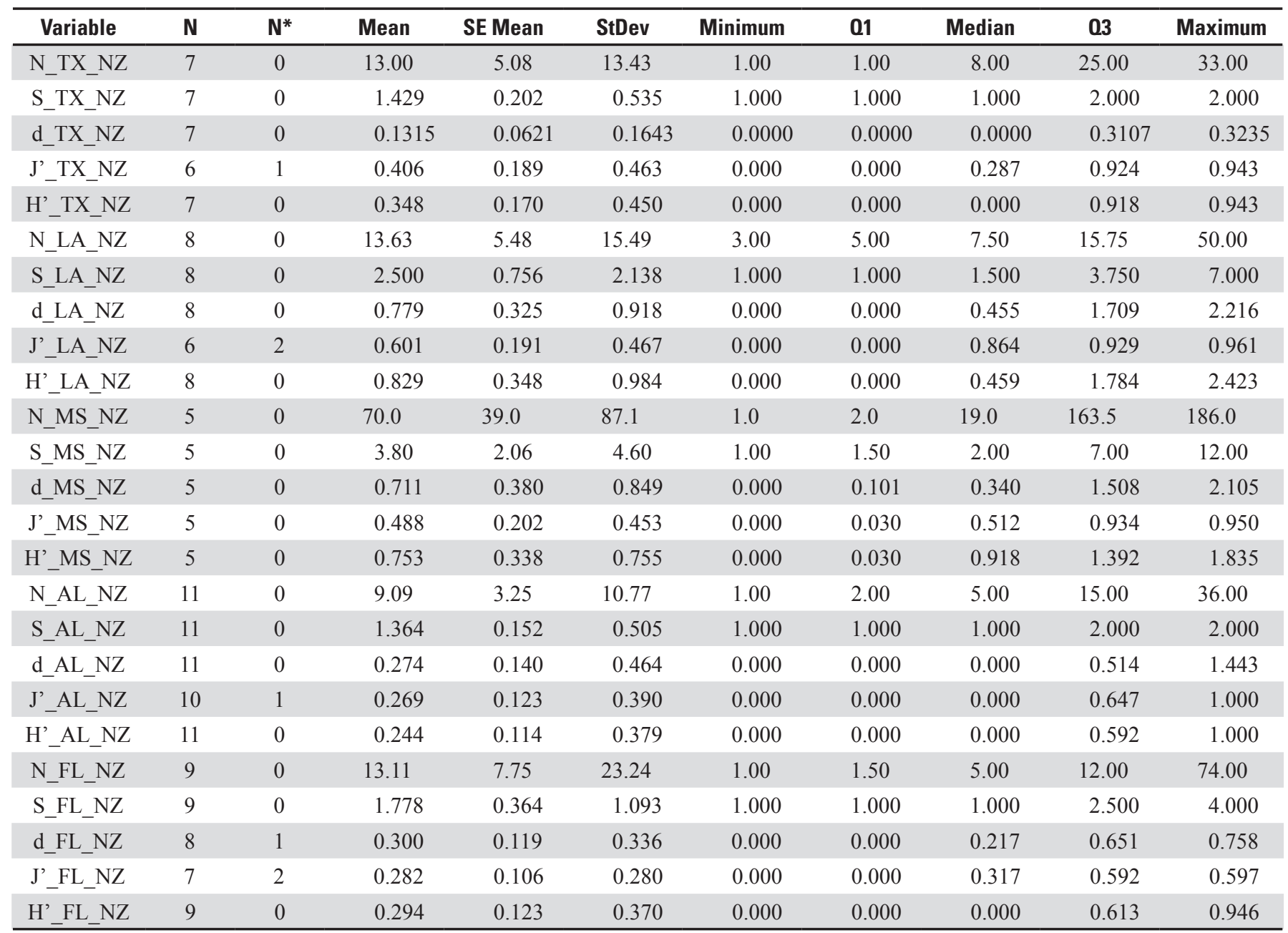


Table A5. Descriptive statistics for all state data, combined. Pseudoreplicates are given as averaged records and zero-abundance samples are included.

\begin{tabular}{cccccccccccc}
\hline Variable & $\mathbf{N}$ & $\mathbf{N}^{*}$ & Mean & SE Mean & StDev & Minimum & Q1 & Median & Q3 & Maximum \\
\hline N & 56 & 0 & 12.44 & 4.35 & 32.52 & 0.00 & 0.00 & 1.00 & 9.25 & 186.00 \\
S & 56 & 0 & 1.286 & 0.267 & 1.997 & 0.000 & 0.000 & 1.000 & 2.000 & 12.000 \\
D & 56 & 0 & 0.2506 & 0.0715 & 0.5349 & 0.0000 & 0.0000 & 0.0000 & 0.2918 & 2.2160 \\
J' & 56 & 0 & 0.2089 & 0.0472 & 0.3535 & 0.0000 & 0.0000 & 0.0000 & 0.4311 & 1.0000 \\
H' & 56 & 0 & 0.2719 & 0.0732 & 0.5478 & 0.0000 & 0.0000 & 0.0000 & 0.3012 & 2.4226 \\
\hline
\end{tabular}

Table A6. Descriptive statistics for all state data, separately. Pseudoreplicates are given as averaged records and zero-abundance samples are included.

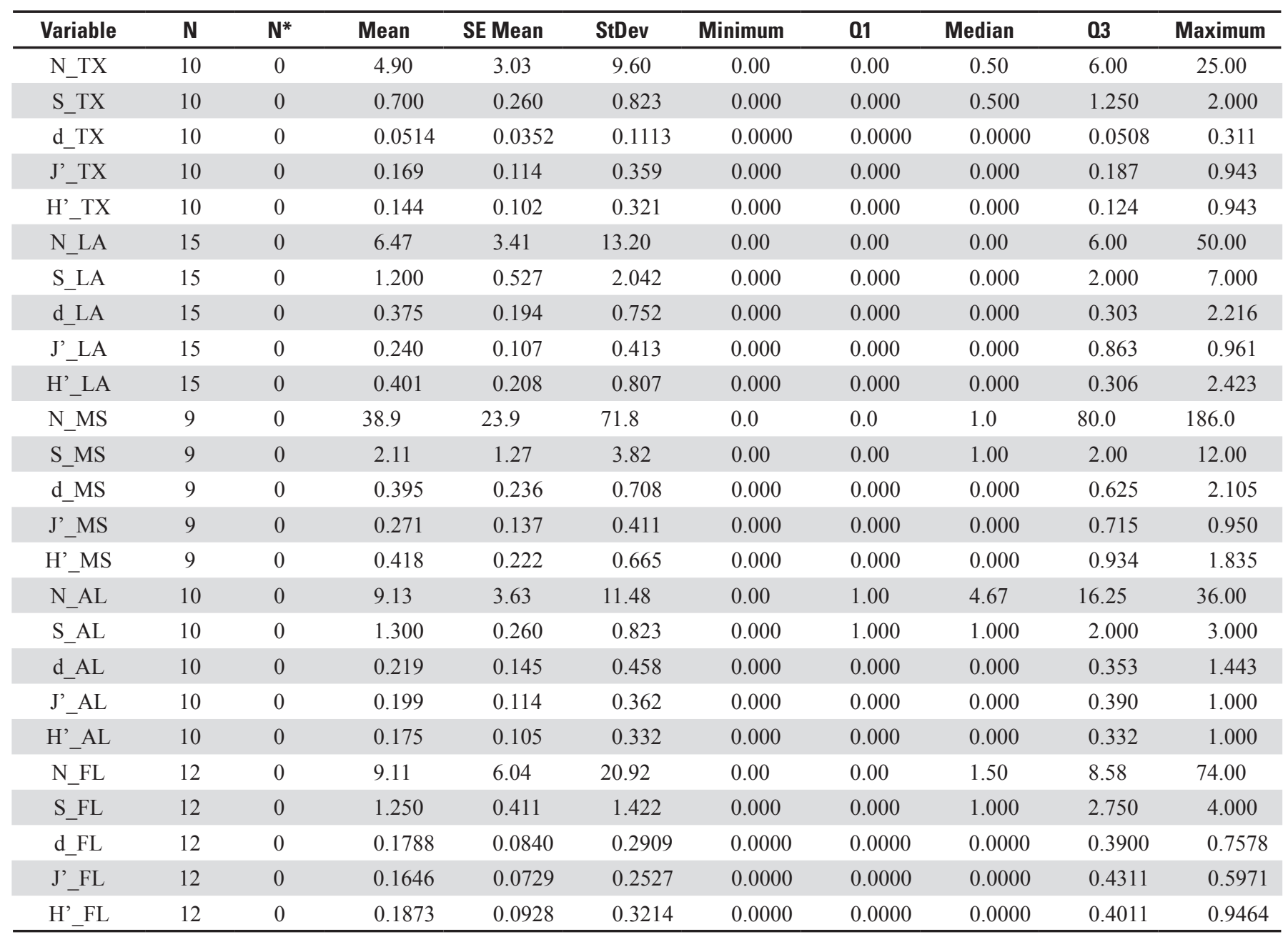


Table A7. Descriptive statistics for all state data combined. Pseudoreplicates are given as averaged records and zero-abundance samples are excluded.

\begin{tabular}{cccccccccccc}
\hline Variable & $\mathbf{N}$ & $\mathbf{N}^{*}$ & Mean & SE Mean & StDev & Minimum & Q1 & Median & Q3 & Maximum \\
\hline N & 32 & 0 & 21.77 & 7.22 & 40.82 & 1.00 & 2.00 & 5.50 & 19.75 & 186.00 \\
S & 32 & 0 & 2.250 & 0.389 & 2.200 & 1.000 & 1.000 & 2.000 & 2.750 & 12.000 \\
D & 32 & 0 & 0.438 & 0.115 & 0.650 & 0.000 & 0.000 & 0.203 & 0.631 & 2.216 \\
J' & 32 & 0 & 0.3656 & 0.0713 & 0.4032 & 0.0000 & 0.0000 & 0.1736 & 0.8338 & 1.0000 \\
H' & 32 & 0 & 0.476 & 0.116 & 0.657 & 0.000 & 0.000 & 0.129 & 0.937 & 2.423 \\
\hline
\end{tabular}

Table A8. Descriptive statistics for all state data, separately. Pseudoreplicates are given as averaged records and zero-abundance samples are excluded.

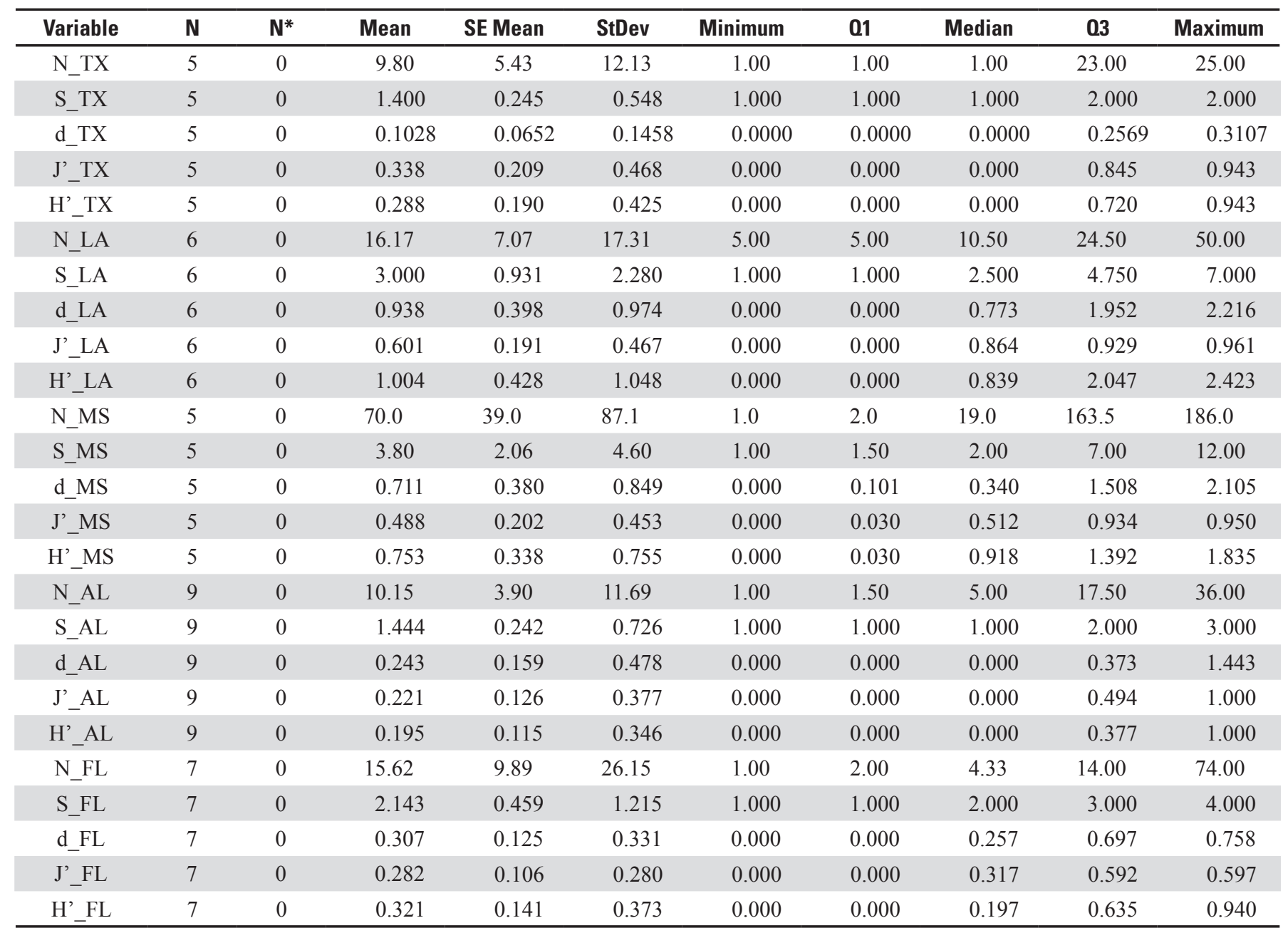






\section{总}

